\title{
Negotiated Health Diplomacy: A Case Study of the E U and Central Asia
}

\author{
Neil Collins, ${ }^{\text {a }}$ Kristina Bekenova ${ }^{\mathbf{a}}$ and Ainur Kagarmanova ${ }^{\mathrm{b}}$ \\ a School of Humanities and Social Sciences, Nazarbayev University, \\ Astana 010000, Kazakhstan \\ b School of Science and Technology, Nazarbayev University, Astana 010000, \\ Kazakhstan \\ neil.collins@nu.edu.kz; kristina.bekenova@nu.edu.kz; \\ ainur.kagarmanova@nu.edu.kz
}

Received: 27 August 2017; revised: 18 March 2018; accepted: 7 May 2018

\section{Summary}

In the soft-power context, health is increasingly seen as an area that generates particular diplomatic benefits, because it is ostensibly non-political and can bring both immediate and long-term advantages to the donor and the recipient country equally. The endeavours of individual member states of the European Union (EU) and the input of the EU itself in Central Asia are examined to see the extent to which the initiatives in health-related areas form part of a wider diplomatic strategy and whether their effectiveness is related to the means by which the planned improved health outcomes are achieved. This article seeks to draw lessons from the European experience to increase understanding of the role of health in global diplomacy.

\section{Keywords}

health diplomacy - health cooperation - European Union - Central Asia

\section{Introduction}

Like other forms of non-traditional international relations, health diplomacy is aimed at achieving benefits through people-to-people interaction in 
non-military and economic areas. It is premised on the idea that, by being seen to bring benefits to the local community, a state raises its status and, therefore, its impact in foreign countries. It is one of the oldest manifestations of what has come to be called 'soft power' — that is, the ability of states to attract and persuade citizens of other countries of their shared interests and intentions. It is, as Laura Roselle et al. would characterize it, a 'strategic narrative'. The important soft-power question is: 'what means and methods of persuasion and influence are likely to work under what conditions?'2

In the soft power context, health is increasingly seen as an area that generates particular diplomatic benefits, because it is ostensibly non-political and can bring both immediate and long-term advantages to the donor and the recipient country equally.

This article examines the endeavours of individual member states of the European Union (EU) and the input of the EU itself to see the extent to which initiatives in health-related areas form part of a wider diplomatic strategy and whether their effectiveness is related to the means by which planned improved health outcomes are achieved. The article seeks to draw lessons from the European experience to understand the role of health diplomacy globally. It is divided into four sections:

- reviewing literature on health diplomacy and developing a working definition;

- outlining the EU's and EU member states' health diplomacy strategies;

- mapping existing European activities in Central Asia; and

- drawing lessons for health diplomacy globally and regionally.

\section{Conceptualizing Health Diplomacy}

Since the 1920s, the international community and governments have been emphasizing the importance of health for economic development and trade, for it was recognized that 'germs and disease-carrying parasites ignore national

1 This project has received funding from the European Union's Horizon 2020 research and innovation programme under grant agreement No 693799. This research has not been submitted for publication, nor has it been published in whole or in part, elsewhere. We attest to the fact that all authors listed above have contributed significantly to the work and agree to its inclusion in The Hague Journal of Diplomacy. J.S. Nye, 'Public Diplomacy and Soft Power', The Annals of the American Academy of Political and Social Science, no. 616 (2008), pp. 94-109.

2 L. Roselle, A. Miskimmon and B. O'Loughlin, 'Strategic Narrative: A New Means to Understand Soft Power', Media, War \& Conflict, vol. 7, no. 1 (2014), p. 71. 
boundary lines and migrate from country to country regardless of political and diplomatic situations.' ${ }^{3}$ In the 1970s, an 'untapped resource' was identified in terms of international health cooperation, and the necessity of collaboration beyond borders on health issues, especially on preventing and controlling communicable diseases. ${ }^{4}$ It is widely accepted that economic growth, political stability, the quality of democracy, poverty and income inequality are all affected, one way or another, by the level of access to health care and a country's ability to deal with diseases. ${ }^{5}$

In the past twenty years, health has become increasingly involved in many spheres of government-to-government cooperation. The new term 'health diplomacy' replaced terms such as 'vaccine diplomacy', ' 'malaria diplomacy'7 and 'medical diplomacy'. ${ }^{8}$ Interest in this field has been evidenced progressively by academic publications. ${ }^{9}$ While nearly unanimous agreement on the importance of health diplomacy exists, there has been much less consensus on how it should be conceptualized and operationalized. Moreover, there is still a question about what the function of diplomacy in global health is. ${ }^{10}$

As David Fidler and many others note, ${ }^{11}$ there is little agreement on the conceptualization of health diplomacy and the variety of perspectives and levels

3 Society for Science and the Public, 'Germs Ignore Diplomatic Alliances', The Science Newsletter, vol. 8, no. 270 (1926), p. 7 .

4 K.M. Cahill, The Untapped Resource: Medicine and Diplomacy (New York: Orbis Books, 1971).

J.P. Mackenbach and M. McKee, 'Government, Politics and Health Policy: A Quantitative Analysis of 30 European Countries', Health Policy, vol. 119, no. 10 (2015), pp. 1298-1308.

6 P.J. Hotez, 'Vaccine Diplomacy', Foreign Policy, vol. 124 (May-June 2001), pp. 68-69.

7 L.-H. Chan, L. Chen and J. Xu, 'China's Engagement with Global Health Diplomacy: Was SARS a Watershed?' PLoS Medicine, vol. 7, no. 4 (2010).

8 P.G. Bourne, 'A Partnership for International Health Care', Public Health Report, vol. 93, no. 2 (1978), pp. 114-123.

9 R. Katz, S. Kornblet, G. Arnold, E. Lief and J.E. Fischer, 'Defining Health Diplomacy: Changing Demands in the Era of Globalization', The Milbank Quarterly, vol. 89, no. 3 (2011), pp. 503-523.

10 D.P. Fidler, 'Health Diplomacy', in A.F. Cooper, J. Heine and R. Thakur (eds), The Oxford Handbook of Modern Diplomacy (Oxford: Oxford University Press, 2013), DoI: 10.1093/ oxfordhb/9780199588862.013.0039.

11 See D.P. Fidler, 'Rise and Fall of Global Health as a Foreign Policy Issue', Global Health Governance, vol. 4 (Spring 2011), retrieved from http://www.ghgj.org/DavidFidler.pdf; K. Lee and R. Smith, 'What is "Global Health Diplomacy"? A Conceptual Review', Global Health Governance, vol. 5, no. 1 (2011), retrieved from http://summit.sfu.ca/item/10865; H. Feldbaum and J. Michaud, 'Health Diplomacy and the Enduring Relevance of Foreign Policy Interests', PLoS Medicine, vol. 7, no. 4 (2010). 
of analysis that have appeared in the context of globalization. As a result of the expansion of the array of state and non-state actors involved, plus the scope of health issues addressed, the phenomenon of health diplomacy itself is more pervasive and sophisticated.

The literature reflects various perspectives:

- Mapping: attempts to identify the various dimensions, among them human rights, international law and trade, with which health diplomacy may be involved and incorporated; ${ }^{12}$ as well as developing typologies and taxonomies $^{13}$ that would enable analysts to chart properly the existing activities in health-related areas.

- Benchmarking: developing standards and indicators to track the implementation of health diplomacy projects in various cultural and religious contexts. $^{14}$

- Globalizing: focused on the global level, these studies research the implementation of the idea of global health diplomacy and global health governance matters as a precondition for development in an interdependent world. ${ }^{15}$

- Contextualizing: research has concentrated on the political, socio-cultural, economic and religious factors that affect the quality of health diplomacy. ${ }^{16}$

- Aligning: assesses health diplomacy's raison d'être and is divided into two camps:

12 See A. Chapman, 'Globalization, Human Rights and the Social Determinants of Health', Bioethics, vol. 23, no. 2 (2009), pp. 97-111; F.M. Abbott, 'The WTO Medicines Decision: World Pharmaceutical Trade and the Protection of Public Health', American Journal of International Law, vol. 99, no. 2 (2005), pp. 317-358; and R. Labonté and M.L. Gagnon, 'Framing Health and Foreign Policy: Lessons for Global Health Diplomacy', Globalization and Health, vol. 6, no. 14 (2010), pp. 1-19.

13 See A.B. Amaya, V. Rollet and S. Kingah, 'What's in a Word? The Framing of Health at the Regional Level: ASEAN, EU, SADC and UNASUR', Global Social Policy, vol. 15, no. 3 (2015), pp. 229-260; and Katz et al., 'Defining Health Diplomacy'.

14 See S. Kevany, 'Diplomatic Advantages and Threats in Global Health Program Selection, Design, Delivery and Implementation: Development and Application of the Kevany Riposte', Globalization and Health, vol. 11, no. 22 (2015); and S. Kevany, 'Global Health Engagement in Diplomacy, Intelligence and Counterterrorism: A System of Standards', Journal of Policing, Intelligence and Counter Terrorism, vol. 11, no. 1 (2016), pp. 84-92.

15 See T.E. Novotny and I. Kickbusch, 'Global Health Diplomacy: A Bridge to Innovative Collaborative Action', Global Forum Update on Research for Health, vol. 5 (2008), pp. 41-45.

16 M. Brown, J. Bergmann, T. Mackey, Q. Eichbaum, L. McDougal and T. Novotny, 'Mapping Foreign Affairs and Global Public Health Competencies: Towards a Competency Model for Global Health Diplomacy', Global Health Governance, vol. x, no. 2 (2016), pp. 3-49. 
a) defines health diplomacy through the normative, or altruistic, lenses; thus, in line with Peter Bourne's notion of 'a new era of responsibility,', it is presented as a process with the potential to improve health situations, thus calling for fighting against internationalized problems by 'going beyond narrow self-interest'; 18 and

b) rejects the 'altruistic' nature by looking at health diplomacy through the perspective of 'enduring relevance of foreign policy interests'. Harley Feldbaum and Joshua Michaud argue that foreign policy interests are critical in understanding health diplomacy initiatives, their priority and its 'spillover' effect. ${ }^{19}$ In this context, the examples of Cuba and China demonstrate that a country's active engagement in global health is primarily driven by a foreign policy agenda to improve the country's international image and increase international influence. ${ }^{20}$

Given the interest that the study of health diplomacy has received in the past two decades, it is not surprising that several efforts have been made to develop a definition. Most characterizations capture several important aspects of health diplomacy. These typically:

- involve a variety of governmental and non-governmental actors;

- assess the foreign policy interests of the donor as well as recipient countries;

- by relying on the 'soft power' of medicine, treatment and technology, attempt to increase the donor's power profile in a particular region; and

- look at health diplomacy's negotiated character, thus broadly defining it as 'the policy-shaping processes through which states, intergovernmental organizations and non-state actors negotiate responses to health challenges or utilize health concepts or mechanisms in policy-shaping and negotiation strategies to achieve other political, economic, or social objectives'. ${ }^{21}$

17 Bourne, 'A Partnership for International Health Care', p. 114.

18 D. Yach, 'Globalization of Public Health, 2: The Convergence of Self-Interest and Altruism', American Journal of Public Health, vol. 88, no. 5 (1998), p. 738.

19 Feldbaum and Michaud, 'Health Diplomacy and the Enduring Relevance of Foreign Policy Interests'.

20 M.C. Werlau, 'Cuba's Health-Care Diplomacy: The Business of Humanitarianism', World Affairs (March-April 2013), retrieved from http://www.worldaffairsjournal.org/article/ cuba\%E2\%80\%99s-health-care-diplomacy-business-humanitarianism;Y. Huang, 'Pursuing Health as Foreign Policy: The Case of China', Indiana Journal of Global Legal Studies, vol. 17, no. 1 (2010), pp. 105-146.

21 The Global Health Diplomacy Network, cited in R. Marten, J. Hanefeld and R. Smith, 'Power: The Nexus of Global Health Diplomacy', Journal of Health Diplomacy, vol. 1, no. 2 (2014). 
This terminological span, to some extent, is testament to the popularity of the concept, which is usually examined through the lens of desired outcomes and goals.

Putting aside the presentation of 'new diplomacy' through the prism of diverse actors and diverse issues, ${ }^{22}$ the outlook here emphasizes the framework of a 'push-pull' effect isolated by Andrew Cooper and Asif Farooq. ${ }^{23}$ In modern diplomacy, as in commerce, ${ }^{24}$ one party follows or promotes their own interests proactively, either through non-traditional means, such as non-governmental engagement, or by direct approaches to local populations. ${ }^{25}$ Whichever strategy is adopted, the practice must, in some way, reflect the foreign policy objectives of the participants. This does not mean that diplomacy is purely instrumental or undertaken for specific policy purposes, but that - to be diplomacy rather than simply philanthropy - it must serve to achieve some political goal and fulfil some level of public accountability. As Fidler suggests:

Increased soft-power use of health demonstrates greater instrumentalization of health for foreign policy purposes, challenging the ethos that health is an end in itself and not a tool for geopolitical machinations. [...] Health as soft power might produce some positive health outcomes, but such outcomes are often not the primary purpose of these strategies. ${ }^{26}$

Indeed, it is this link to mainstream policy priorities that ensures health diplomacy's significance:

[...] health diplomacy advances the possibility that politics can serve goals of health. [...] Yet, diplomats in the world of health politics must [...] work within political arenas, calling for policies and practices that transcend conflicting political interests while also catering to those same specific interests to achieve positive health outcomes. ${ }^{27}$

22 A.F. Cooper, J. Heine and R. Thakur (eds), The Oxford Handbook of Modern Diplomacy (Oxford: Oxford University Press, 2013).

23 A.F. Cooper and A.B. Farooq, 'Stretching Health Diplomacy Beyond "Global" Problem Solving: Bringing the Regional Normative Dimension In', Global Social Policy, vol. 15, no. 3 (2015), p. 316.

24 G.R. Dowling, The Art and Science of Marketing (Oxford: Oxford University Press, 2004).

25 Cooper and Farooq, 'Stretching Health Diplomacy Beyond “Global" Problem Solving'.

26 Fidler, 'Rise and Fall of Global Health as a Foreign Policy Issue'.

27 V. Adams, 'A History of Global Health Encounters: Diplomacy in Transition', in T.E. Novotny, I. Kickbusch and M. Told (eds), 21st-Century Global Health Diplomacy (Singapore: World Scientific, 2013), p. 43. 
In short, this article is presaged on a narrow definition of health diplomacy. Health diplomacy must be:

- separate from disaster relief and short-term humanitarian aid;

- based on long-term objectives that advance the foreign policy goals of the donor country;

- responsive to the expressed needs of the recipient state.

The article also suggests that health diplomacy is more relevant in cases where the medical capacities of the donor and recipient countries lack congruence and where the post-Cold War multi-polarity of international relations necessitates the expansion of relations with new partners. The case study below thus looks at a former Soviet space and examines health diplomacy as a significant instrument to improve cooperation with countries that appear to 'be closed'. The article examines European endeavours to increase the engagement of five Central Asian states (Kazakhstan, Kyrgyzstan, Tajikistan, Turkmenistan and Uzbekistan) with the international community by opening them to more proactive behaviour in dealing, in the first instance, with health issues, and further to facilitate regional and intra-regional integration and cooperation. As Neil Collins and Kristina Bekenova assert, it is important to develop an understanding of this region that acknowledges the realities of the new 'great game' and is willing to change its patterns of behaviour according to the new role that it wants to play in global politics. ${ }^{28}$

Health diplomacy, as Bourne noted, is 'the basis for establishing a dialogue and bridging diplomatic barriers because [it] transcend[s] traditional and more volatile and emotional concerns.' ${ }^{29}$ As Ilona Kickbusch and Mihály Kõkény suggest, 'global health diplomacy, if well conducted, results in improved global health, greater quality, better relations and trust between states and strengthens commitments on the part of stakeholders to work together to improve health nationally and globally.' ${ }^{30}$

Using the notion of health diplomacy as understood above, this article maps and analyses the use of health diplomacy by the EU in Central Asian countries.

28 N. Collins and K. Bekenova, 'Fuelling the New Great Game: Kazakhstan, Energy Policy and the EU', Asia Europe Journal, vol. 15, no. 1 (2017), pp. 1-20.

29 Bourne, 'A Partnership for International Health Care', p. 121.

$30 \quad$ I. Kickbusch and M. Kõkény, 'Global Health Diplomacy: Five Years On', Bulletin of the World Health Organization, vol. 91, no. 3 (2013). 


\section{European Health Diplomacy}

According to the analytical framework proposed by Henrik Larsen ${ }^{31}$ and applied by Vincent Rollet and Peter Chang, ${ }^{32}$ 'gradual involvement' characterizes the EU's approach to health diplomacy. The EU is 'expected to have a central role to play in global health by governmental and non-governmental actors within and outside Europe. ${ }^{33}$ This expectation is premised upon two assertions:

- the EU's increasing role in the international policy arena makes its participation in global health inevitable; ${ }^{34}$ and

- European values of solidarity point towards equitable and universal access to quality health services.

Guided by several health-related documents, ${ }^{35}$ the European approach to health is framed as an integral part of development, human rights, security and global public goods, thus making EU involvement imperative. ${ }^{36}$ The EU, as well as its member states, has acknowledged the importance of addressing health issues not only from the position of 'moral obligation', but also from the pragmatic stance that 'it is in our own interests [in case of communicable diseases]. ${ }^{37}$ Thus, approaching it from various perspectives and levels, health is becoming a domain of foreign policy and international cooperation for the EU that provides a significant soft-power tool. According to the European Commission, globalization created:

[...] many positive developments on health, such as the increase in opportunities for cross-border health-related transactions, trans-national cooperation, support, and knowledge sharing. [...] Sharing expertise, experience and best practice in global health is essential for research,

31 H. Larsen, Analysing the Foreign Policy of Small States in the EU and the Case of Denmark (Houndmills: Palgrave Macmillan, 2005).

32 V. Rollet and P. Chang, 'Is the European Union a Global Health Actor? An Analysis of its Capacities, Involvement and Challenges', European Foreign Affairs Review, vol. 18, no. 3 (2013), pp. 309-328.

33 Rollet and Chang, 'Is the European Union a Global Health Actor?', p. 328.

34 European Commission, Health: Commission Calls on EU to Gear Up on Health Actions (2010).

35 See European Commission, Together for Health: A Strategic Approach for the EU, 2008-2013 (2007); Contributing to Universal Coverage of Health Services through Development Policy (2010); and The EU Role in Global Health (2010).

36 Amaya, Rollet and Kingah, 'What's in a Word?'.

37 European Commission, Contributing to Universal Coverage of Health Services through Development Policy. 
governance, coordination and cooperation within and outside the EU. The EU works on different fronts to achieve dissemination of knowledge, the promotion of EU values and principles and capacity building. ${ }^{38}$

In 2010, both the European Commission and Council called for coordinated action to ensure that Europe was meeting health challenges. ${ }^{39}$ In looking at both the member states and the $\mathrm{EU}$, however, this analysis needs to acknowledge that the collective body suffers from:

[... the individual] Member States' [... lack of] trust in EU representation and reluctance to cede competence on health matters, lack of EU flexibility in negotiations, lengthy EU coordination processes, Member States vying for influence within the EU, and Member States rather than EU engagement in behind the scenes and 'soft power' diplomacy. ${ }^{40}$

Ambiguities do exist in the area of health policy about the scope of national and European competences. ${ }^{41}$ At a member-state level, the main ambitions of health policy are clear: 'universal access for all citizens, effective care for better health outcomes, efficient use of resources, high-quality services and responsiveness to patient concerns. It is a formula that resonates across the political spectrum, 42

Domestic discourse is predominantly about the speed of implementation and sharing of the financial burden. In this respect, 'all [health] politics is local'. Nevertheless, as Samantha Battams et al. concede, 'the EU is a significant player in global health, ${ }^{43}$ so its independent role needs to be examined. Similarly, the function of the smaller EU member states may be unusually important as they 'use the health arena to demonstrate their commitment to the multilateral systems that provide them with a voice and allow them a leading

38 European Commission, Global Health: Responding to the Challenges of Globalization (2010).

39 European Commission, Contributing to Universal Coverage of Health Services through Development Policy.

40 S. Battams, L. van Schaik and R. van de Pas, 'The EU as a Global Health Actor: Policy Coherence, Health Diplomacy and WHO Reform', European Foreign Affairs Review, vol. 19, no. 4 (2014), p. 539.

M. Guy and W. Sauter, The History and Scope of EU Health Law and Policy, Working Paper no. 16-2 (Norwich: University of East Anglia, Centre for Competition Policy, 2016).

M. McKee, J. Healy and J. Falkingham (eds), Healthcare in Central Asia (London: Open University Press, 2002), p. vii.

43 Battams, van Schaik and van de Pas, 'The EU as a Global Health Actor', p. 539. 
role on the global stage. ${ }^{44}$ Thus, health diplomacy offers an intriguing insight into the dynamics of the $\mathrm{EU}$ itself.

The primary target issues of the EU's health funding and programmes are: strengthening health care systems; improving the quality of reproductive health and rights; as well as researching epidemics and non-communicable diseases, 'with a particular emphasis on the regional dimension and on candidate, potential candidate and the European Neighbourhood Policy countries.'45 Nevertheless, the challenges remain. Lack of coherence and coordination between $\mathrm{EU}$ health and other policies demonstrates that the $\mathrm{EU}$ is an 'actor still in construction, ${ }^{46}$ a characteristic much in evidence in its approaches to Central Asia, a region that is very slowly becoming of interest to Europe.

\section{European Union and Health Cooperation in Central Asia}

Health cooperation between the EU and Central Asian countries can be traced to 1992 as humanitarian aid, but since 2007 it has gained new traction with the publication of the EU Regional and Country Strategy Papers, where health was addressed officially for the first time. ${ }^{47}$ Before that, the Eu's focus was largely confined to energy, security and democratization, with health a part of humanitarian assistance for the region. In 2007, it was observed that AIDS/ HIV, malaria, tuberculosis, child mortality, poor water quality, air pollution and deteriorating health care services were critical issues that should also be taken into account. The political priority afforded to combatting HIV in both Europe and Central Asia has been evidenced on several occasions, including in the 2004 Dublin Declaration on Partnership to fight HIV/AIDS in Europe and Central Asia, which promised to 'make the fight against HIV/AIDs in Europe and Central Asia a regular item on the agendas of our regional institutions and organizations', ${ }^{\prime 8}$ and the ongoing monitoring project by the European Centre

44 I. Kickbusch, '21st-Century Health Diplomacy: A New Relationship between Foreign Policy and Health', in T.E. Novotny, I. Kickbusch and M. Told (eds), 21st-Century Global Health Diplomacy (Singapore: World Scientific, 2013), p. 14.

45 European Commission, Global Health: Responding to the Challenges of Globalization.

46 Rollet and Chang, 'Is the European Union a Global Health Actor?', p. 328.

47 European Community, Regional Strategy for Paper for Assistance to Central Asia for the Period 2007-2013 (2007).

48 World Health Organization, Dublin Declaration on Partnership to Fight HIV/AIDS in Europe and Central Asia (2004). 
for Disease Prevention and Control. ${ }^{49}$ The 2007 Strategy has been reviewed on several occasions and was further revised when Latvia assumed the rotating EU presidency in 2015. Riga placed Central Asia among its top priorities. ${ }^{50}$

In summarizing European health diplomacy initiatives, the outline below will refer to some that are characterized by joint action or 'partnership' and others that are primarily aid or 'provision'. Partnership actions seek to harness the synergy of collaboration, while provision actions address needs primarily identified by the donor. For both categories, Ronald Labonté and Michelle Gagnon's assertion about health diplomacy remains valid.. ${ }^{51}$ Policy-makers "still make decisions primarily on the basis of the "high politics" of national security and economic material interests. ${ }^{52}$ Furthermore, a distinction is made between the activities deriving from EU initiatives and those reflecting member-state actions, although, as with partnership and provision, the line between the two categories is not always clear-cut. The data underlying the analysis of European health diplomacy rely primarily on academic, EU and governmental documentation, semi-structured interviews with key informants in Brussels and Astana, as well as direct enquiries to relevant ministries and embassies of the EU member states.

\section{EU Actions}

At least regarding official rhetoric, 2007 represents a turning point in EU/ Central Asia relations with a new emphasis on the idea of partnership. ${ }^{53}$ Currently, the extent of EU involvement in regional health activities comprises various instruments, thematic programmes and collaboration with international organizations (see Table 1 below).

For the EU, 'investing in capacity for protecting health and responding to health needs can be understood as an investment in stability'. ${ }^{4}$ With its approach to Central Asia, the EU considers 'development assistance for health as a tool to fight poverty, support development and reach the MDGs [Millennium

49 European Centre for Disease Prevention and Control, Background and Methods Monitoring Implementation of the Dublin Declaration on Partnership to Fight HIV/AIDS in Europe and Central Asia: 2012 Progress Report (Stockholm: ECDC, 2013).

50 Latvian Presidency of the Council of the European Union, Priorities and Programme of the Latvian Presidency (2015).

$51 \quad$ Labonté and Gagnon, 'Framing Health and Foreign Policy'.

$5^{2}$ Labonté and Gagnon, 'Framing Health and Foreign Policy', p. 1.

53 General Secretariat of the Council, The European Union and Central Asia: The New Partnership in Action (Brussels: General Secretariat of the Council, 2009).

54 S. Møgedal and B.L. Alveberg, 'Can Foreign Policy Make a Difference to Health?' PLoS Medicine, vol. 7 , no. 5 (2010). 
Development Cooperation

Instrument (which replaced

Technical Assistance to the

Commonwealth of Independent

States (TACIS) in 2007)

Instrument for Stability
Supports the health sector through capacitybuilding programmes, technical assistance for health reforms, maternal and child services, and prevention of diseases, etc.

Addresses global security and development challenges and provides biosafety and biosecurity cooperation with the region, including research cooperation via the International Science and Technology Centre (ISTC)

Investment Facility for Central Asia Allocates E U development grants to implement infrastructure projects in the region that have a significant positive impact on health

Non-State Actors and Local Authorities in Development

Avian and Human Influenza Facility (with small Eu funding)
Aims to support local participation in development, improve governance and facilitate access to health services

Aimed to combat the threat of avian and human influenza in Central Asia

Development Goals]; in this approach [...] investments in non-member states have the potential to open new economic opportunities and markets to the region'. 55

For 2007-2013, the EU Regional Strategy for Assistance to Central Asia allocated an overall budget of $€ 673.8$ million for bilateral and regional cooperation, where $€ 139.5$ million was allocated specifically for health and social protection with the aim to 'bring the legislation and practice of the partner countries closer to those of the most important E U policies and standards'. ${ }^{56}$ In Kazakhstan, this budget was allocated to support the capacity-building initiatives of the Ministry of Health to implement the state programme on healthcare reform and development; in Uzbekistan, to improve maternal and child

55 Amaya, Rollet and Kingah, 'What's in a Word?', p. 243.

56 European Commission, European Union-Central Asia Development Cooperation (2011). 
health systems; and in Tajikistan, to develop the health management information system.

In line with these policy commitments, health may have gradually become one of the significant areas of scientific cooperation between the EU and Central Asia through its Research Framework Programmes (FP 4-7 and Horizon 2020). According to the analysis of the research projects under the Framework Programmes, Horizon 2020 and the International Science and Technology Centre (ISTC, sponsored by the EU), Kazakhstan, Kyrgyzstan and Tajikistan are the main scientific partners involved in 127,58 and 23 research projects respectively in areas of health (biosafety and life sciences) and the environment (see Table 2 below). In research terms, Central Asian scientists are becoming increasingly engaged with EU universities and institutions through conferences and workshops, etc. This development is widening the geographic scale of scientific networking and engagement.

ISTC Executive Director David Cleave, stated in an interview that the EU plays an increasingly important role as a scientific actor whose health-related initiatives integrate a wider concept of biosafety and biosecurity, which get funding under the Instrument of Stability. The EU — as the ISTC's partner examines the scientific cooperation with Central Asian countries at the regional level as a clear priority, thus bringing scientists and policy-makers from the whole region together. From sponsoring joint research projects, in 2015 the EU changed its focus of attention towards programmes that include training medical and science personnel, law enforcement, improving biosafety and biosecurity standards, the provision of equipment and construction of laboratories. This agenda is partially explained by a budget reduction and somewhat by the Eu's rather ad-hoc collaboration with Central Asian countries. Fighting

TABLE 2 The EU and Central Asia: Science for diplomacy

\begin{tabular}{llllll}
\hline & $\begin{array}{l}\text { ISTC: } \\
\text { Health }\end{array}$ & $\begin{array}{l}\text { ISTC: } \\
\text { Environment }\end{array}$ & $\begin{array}{l}\text { FP/Horizon: } \\
\text { Health }\end{array}$ & $\begin{array}{l}\text { FP/Horizon: } \\
\text { Environment }\end{array}$ & Total \\
\hline Kazakhstan & 48 & 49 & 18 & 12 & 127 \\
Kyrgyzstan & 21 & 27 & 5 & 5 & 58 \\
Tajikistan & 13 & 7 & 2 & 1 & 23 \\
Uzbekistan & 0 & 0 & 7 & 6 & 13 \\
Turkmenistan & 0 & 0 & 1 & 3 & 4 \\
\hline
\end{tabular}

SOURCE: ISTC ANNUAL REPORTS; HORIZON 2020/FP4-7 DATABASE 
communicable diseases is the priority of the EU's cross-border cooperation with the region.

Schemes aimed at facilitating programmes and joint research projects on poverty-related diseases frequently involve the $\mathrm{EU}$ or member states in joint ventures with other organizations such as the United Nations Development Programme (UNDP) and World Health Organization (WHO). Similarly, the European Centre for Disease Prevention and Control (ECDC), an independent EU agency, works in Central Asia to reinforce Europe's defences against infectious diseases. The Eu also funds the Central Asia Drug Action Programme through a consortium involving the Netherlands, Czech Republic, Poland and Germany. ${ }^{57}$

The EU's main funding is for humanitarian actions in response to natural disasters. Between 1994 and 2015, this amounted to over $€ 222$ million. Health diplomacy is expressed in such activities as conducting training, constructing health facilities, supporting health-care reforms and delivering health services (see Table 3 below).

The EU's assistance programme is broadly tailored to the Central Asian states' priorities. Although the European Commission favours a regional approach, the level of development and political stability of the five Central Asian countries is too varied for such a policy to be applied universally. For example, since 2014, Kazakhstan has not qualified for bilateral assistance from the EU. Nevertheless, it participates in the regional Development Cooperation Instrument programme for Central Asia for 2014-2020.

In an indirectly health-related initiative, in 2015 the $\mathrm{EU}$ funded a project in Kyrgyzstan on the control and remediation of former uranium mines. In broader geopolitical terms, 'while political tumult rocked the country from within [following coups in 2005 and 2010], Kyrgyzstan assumed an outsize role on the international stage. 58

After independence, Tajikistan suffered a five-year civil war. The 2014-2020 Multi-Annual Indicative Programme, which is the basis for EU-Tajik development cooperation, focuses on three priorities: an allocation for health of $€ 62$ million; $€ 75$ million for education; and $€ 110$ million for rural development. The Eu-funded project, Health Management Information System in Tajikistan,

57 Delegation of the European Union to the Kyrgyz Republic, 'CADAP Discussed Work Plans with National Partners in Central Asia' (6 February 2017).

58 P. Shishkin, 'Kyrgyzstan's Most Wanted: The Curious Case of Eugene Gourevitch', Foreign Affairs, vol. 92, no. 6 (31 October 2013). 
TABLE 3 Indicative table on EU assistance to Central Asia

\begin{tabular}{|c|c|c|c|}
\hline Training & $\begin{array}{l}\text { Construction of health } \\
\text { facilities }\end{array}$ & $\begin{array}{l}\text { Delivery of } \\
\text { health services }\end{array}$ & $\begin{array}{l}\text { Education/Health } \\
\text { reforms }\end{array}$ \\
\hline $\begin{array}{l}\text { Biological and } \\
\text { Ecological Safety } \\
\left(\mathrm{CIS}^{* *}, 2000\right)\end{array}$ & $\begin{array}{l}\text { Creation of Regional } \\
\text { Biosafety Training } \\
\text { Centre in Dushanbe } \\
\text { for Capacity Building } \\
\text { for Tajikistan } \\
\text { and Afghanistan } \\
\text { Professionals (2013) }\end{array}$ & $\begin{array}{l}\text { Treatment of } \\
\text { patients with } \\
\text { severe burns, } \\
\text { Kyrgyzstan } \\
(2016)\end{array}$ & $\begin{array}{l}\text { Medical Physics: New } \\
\text { ICT-based curricula } \\
\text { ( } 5 \text { Universities } \\
\text { in Uzbekistan, } \\
\text { 2015-2018) }\end{array}$ \\
\hline $\begin{array}{l}\text { Increasing Threat } \\
\text { of Infectious } \\
\text { Diseases (CIS, } \\
2001 \text { ) }\end{array}$ & $\begin{array}{l}\text { Restoration of } \\
7 \text { blood-transfusion } \\
\text { stations, purchase of } \\
\text { medical equipment, } \\
\text { mobile blood } \\
\text { donation stations } \\
\text { (Kyrgyzstan, 2016) }\end{array}$ & & $\begin{array}{l}\text { Modernising health } \\
\text { education in university } \\
\text { (3 Universities in } \\
\text { Kazakhstan, and } \\
9 \text { Universities } \\
\text { in Uzbekistan, } \\
2015^{-2018)}\end{array}$ \\
\hline $\begin{array}{l}\text { Interaction of } \\
\text { CIs participants } \\
\text { in the area } \\
\text { of Sanitary } \\
\text { Monitoring } \\
(2001)\end{array}$ & $\begin{array}{l}\text { Equipment for early } \\
\text { laboratory diagnosis } \\
\text { of echinococcosis/ } \\
\text { alveococcosis in } \\
\text { National Surgical } \\
\text { Centers in Osh and } \\
\text { Naryn (Kyrgyzstan, } \\
\text { 2016-2018) }\end{array}$ & & $\begin{array}{l}\text { Advancing } \\
\text { university education } \\
\text { in biomedical } \\
\text { engineering and } \\
\text { health management } \\
\text { ( } 7 \text { universities in } \\
\text { Kyrgyzstan, } \\
2015^{-2018)}\end{array}$ \\
\hline $\begin{array}{l}\text { Biosafety and } \\
\text { Biosecurity } \\
\text { Workshop for } \\
\text { Central Asia and } \\
\text { Caucasus region } \\
(2004)\end{array}$ & $\begin{array}{l}\text { Construction of the } \\
\text { National perinatal } \\
\text { centre in Bishkek } \\
\text { (Kyrgyzstan, 2016) }\end{array}$ & & $\begin{array}{l}\text { Development of the } \\
\text { first national standards } \\
\text { for the protection } \\
\text { of motherhood } \\
\text { (Kazakhstan, } \\
\text { Tajikistan, } \\
\text { Turkmenistan, } \\
2012-2015 \text { ) }\end{array}$ \\
\hline
\end{tabular}


TABLE 3 Indicative table on EU assistance to Central Asia (cont.)

\begin{tabular}{|c|c|c|c|}
\hline Training & $\begin{array}{l}\text { Construction of health } \\
\text { facilities }\end{array}$ & $\begin{array}{l}\text { Delivery of } \\
\text { health services }\end{array}$ & $\begin{array}{l}\text { Education/Health } \\
\text { reforms }\end{array}$ \\
\hline $\begin{array}{l}\text { Transportation } \\
\text { of Infectious } \\
\text { Substances, } \\
\text { Animal Biosafety } \\
\text { and Facilities, } \\
\text { Serological } \\
\text { Methods of } \\
\text { Investigation } \\
\text { (2oog-2010, } \\
\text { Kazakhstan) }\end{array}$ & $\begin{array}{l}\text { Construction of } \\
\text { feldscher points in } \\
\text { Kyrgyzstan (2014) }\end{array}$ & & $\begin{array}{l}\text { Development of the } \\
\text { first accreditation } \\
\text { standards for } \\
\text { the protection } \\
\text { of motherhood } \\
\text { (Kazakhstan, } \\
\text { Tajikistan, } \\
\text { Turkmenistan, } \\
2012-2015 \text { ) }\end{array}$ \\
\hline $\begin{array}{l}\text { Development } \\
\text { of the Manual } \\
\text { on Especially } \\
\text { Dangerous } \\
\text { and Zoonotic } \\
\text { Diseases (2010- } \\
2011, \text { ISTC, } \\
\text { Kazakhstan) }\end{array}$ & $\begin{array}{l}\text { Construction of } \\
\text { the central district } \\
\text { hospital in Yavan } \\
\text { (Tajikistan, 2014) }\end{array}$ & & $\begin{array}{l}\text { Equity in health } \\
\text { care financing and } \\
\text { delivery (Kyrgyzstan, } \\
2001-2005 \text { ) }\end{array}$ \\
\hline $\begin{array}{l}\text { International } \\
\text { Workshop } \\
\text { on Probiotics } \\
\& \text { Health } \\
(2010, \text { CIS })\end{array}$ & & & \\
\hline
\end{tabular}

SOURCE: MINISTRIES OF HEALTH, ISTC REPORTS

has been in place since 2007. Phase IV, which began in January 2017 and ran until April 2018, had a budget of $€ 400,000.59$

In Turkmenistan:

[...] there is a health crisis similar to, but more severe than, in other Central Asian countries. [...] Dictatorship [had a] negative impact on

59 EPOS Health Management, Health Management Information System in Tajikistan Phase IV (2016). 
population health: the regime's policy of secrecy and denial, which sees the 'solution' to health care problems in concealment rather than prevention; its complicity in the trafficking of drugs from Afghanistan; and the neglect of its health care system. ${ }^{60}$

This conclusion draws its evidence from the dictatorship of President Niyazov, who died in 2006. Turkmenistan's political system, however, remains particularly authoritarian and its health statistics dubious. For example, "Turkmenistan reported a maternal mortality rate of 3.8 per 100,00o live births in $2012[\ldots]$ but this, like many other health indicators reported from Turkmenistan, is hardly credible'. ${ }^{61}$ It has been reported that:

[...] health-care services in Turkmenistan have deteriorated in recent years, because of the dated professional training, the dismissal of 15,000 health workers in 2004, and lack of medical establishments, equipment, supplies and drugs. The number of qualified health-care staff is extremely small. ${ }^{62}$

Again, in 2010 Turkmenistan's health service came to international attention when:

Médecins Sans Frontières left [...] after 10 years [as its] continued presence would have made it inadvertently complicit in hiding what is going on in Turkmenistan's health-care system. Health-care workers at all levels risk being fined, sacked, or even imprisoned if they do not falsify reports so that targets for health indicators are met. ${ }^{63}$

An indication of the difficulties of using health issues as a diplomatic tool is the incredulity of official figures. Central Asia has 'witnessed one of the fastest growing HIV/AIDS epidemics worldwide, [but...] Turkmenistan is a special case, as it has only reported a total of two infections over the period 1990-2012.

6o B. Rechel and M. McKee, 'The Effects of Dictatorship on Health:The Case of Turkmenistan', BMC Medicine, vol. 5, no. 21 (2007)/1741-7015-5-21.

61 B. Roberts, M. Karanikolos and B. Rechel, B. 'Health Trends', in B. Rechel, E. Richardson and M. McKee (eds), Trends in Health Systems in the Former Soviet Countries (Copenhagen: European Observatory on Health Systems and Policies, 2014), p. 11.

62 Labrys \& Sexual Rights Initiative, Submission on Turkmenistan: Third Round of the Universal Periodic Review (2008).

63 'State of Turkmenistan's Health System' [editorial], The Lancet, vol, 375 (2010), p. 1408. 
[...] These figures are hardly credible' ${ }^{64}$ The local elite would be loath to permit health cooperation either as partnership or provision that would question the status quo.

Uzbekistan is less outward looking than some other Central Asian states. ${ }^{65}$ Its relations with the EU have fluctuated since the Partnership and Cooperation Agreement was signed in 1996. Uzbekistan's reputation for repression remained a barrier to close cooperation:

[...] while many major international organizations, including the wно and USAID, work in cooperation with the government on various healthcare projects, $[. .$.$] speaking out in any way against the authorities could$ have 'serious consequences' for their operations. ${ }^{66}$

The EU's main focus has nonetheless been on human rights, energy and, to some degree, health. Between 2012 and 2015, the EU spent $€ 4.9$ million on the Improvement of Mother and Child Health Services in Uzbekistan. This funding is mostly for training health-care professionals on issues of new-born and child survival. ${ }^{67}$

Since gaining their independence, the five Central Asian countries Kazakhstan, Kyrgyzstan, Tajikistan, Turkmenistan and Uzbekistan - have been cooperating with the $\mathrm{EU}$ in terms of economic, social and political development. Such areas as governance, the environment, energy and education have become a solid basis for cooperation. For the period 2014-2020, the EU allocated $€_{1}$ billion for various projects in the Central Asian republics in the fields of the rule of law and rights, education and rural development, a sum that increased from $€_{75} 0$ million for 2006-2013. Meanwhile, EU financial assistance in the form of humanitarian aid to Central Asia between 1991 and 2004 is estimated at $€ 1.132$ billion. ${ }^{68}$ The EU seeks to engage a broad range of civil society in the five states but, as Vera Axyonova and Fabienne Bossuyt suggest,

64 S. Ancker and B. Rechel, 'Policy Responses to HIV/AIDS in Central Asia', Global Public Health, vol. 10, no. 7 (2015), pp. 817-818.

65 M.S. Fish, 'What has a Quarter Century of Post-Communism Taught Us About the Correlates of Democracy?' in M.S. Fish, G. Gill and M. Petrovic (eds), A Quarter Century of Post-Communism Assessed (London: Springer, 2016), pp. 11-40.

66 E. Holt, 'Uzbekistan Accused of Forced Sterilization Campaign', The Lancet, vol. 379, no. 9835 (2012), p. 2415 .

67 EU Liaison Office in Turkmenistan. 'EU-Uzbekistan Relations' (3 October 2016).

68 'Eurosoyuz vydelyaet stranam Tsentralnoi Azii odin milliard evro', Interactivnoye soobschestvo (21 October 2014), retrieved from http://cso-central.asia/evrosoyuz -vydelyaet-stranam-centralnoj-azii-odin-milliard-evro/. 
compromises are also necessary: 'the $\mathrm{EU}$ customizes its civil society assistance depending on the realities on the ground and at times finds itself empowering state-led civil society, while communal groups rarely benefit from the EU assistance schemes. ${ }^{69}$

\section{Actions by EU Member States}

The relations between individual EU member states and their Central Asian counterparts with regard to health diplomacy are quite varied. Some member states, such as Sweden, Estonia, Belgium and the Netherlands, afford the region little or no priority in terms of targeted assistance, while others are active sponsors of health diplomacy. On the bilateral level, it is possible to point to the role of both Germany and the United Kingdom (UK) in their assistance to the Kyrgyz Republic, ${ }^{70}$ Tajikistan and Uzbekistan, where health is prioritized, along with public administration and water, in poverty-reduction activities. ${ }^{71}$ The British provide what they term 'aid-related frontline diplomacy' in all the Central Asian states.

The UK has been engaging with health issues in Central Asia via the Department for International Development (DFID) since 1997, working on different levels: ministerial - by supporting the reforms of the national health strategies; communal - on HIV/AIDS and tuberculosis and by strengthening the delivery of medical emergency help; and university — analytical work on health. Through technical assistance, programme-based support and a health-sector budget support programme, DFID is aiming to reduce poverty and achieve the MDGs in Kyrgyzstan and Tajikistan. While there are no bilateral health programmes between the UK and Kazakhstan, Turkmenistan and Uzbekistan, the British engage with these republics through multilateral agencies. ${ }^{72}$

In 2013, Germany published a strategic document called Shaping Global Health, Taking Joint Action, Embracing Responsibility that signalled, in part, the

69 V. Axyonova and F. Bossuyt, 'Mapping the Substance of the EU's Civil Society Support in Central Asia: From Neo-Liberal to State-Led Civil Society', Communist and PostCommunist Studies, vol. 49, no. 3 (2016), p. 207.

70 See GOV.UK, 'UK Minister Arrives in Kyrgyzstan to Discuss Cooperation', available at https://www.gov.uk/government/news/uk-minister-arrives-in-kyrgyzstan-to-discuss -cooperation (18 February 2016).

71 European Commission, Strategy Paper 2002-2006 and Indicative Programme 2002-2004 for Central Asia (2002).

72 A. Walker, 'The United Kingdom and Central Asia', EUCAM National Policy Series, vol. 3 (2012). 
'emergence of health issues in their international diplomacy activities. ${ }^{73}$ In accordance with its global strategy, Germany earlier issued a Regional Health Sector Strategy for Central Asia (in 2010), where health was stated as the priority area of cooperation with Kyrgyzstan, Tajikistan and Uzbekistan. According to this strategy, the fundamental German interest in all three countries is to promote sexual and reproductive health and rights, to prevent HIV and tuberculosis, and to improve the efficiency and quality of the health system. With this aim, there are several ongoing projects, primarily in Kyrgyzstan, Tajikistan and Uzbekistan, funded by the German Agency for International Cooperation and implemented on a partnership basis with the close collaboration of ministries of health, local administrations and such institutes as KfW Development Bank (investments), InWEnt (training and e-learning of medical personnel), CIM (the placement of health experts in Central Asia) and DAAD (health-related research). Health diplomacy in Kazakhstan and Turkmenistan is officially classified under Germany's multi-country cooperation with Central Asia.

Although France has embassies in all five states:

Central Asia is by no means set to become a high priority for Paris. It will most likely receive even less attention in the near future, as France looks towards its regions of traditional influence. [...] France hopes to continue to delegate much of its involvement in Central Asia to European bodies. ${ }^{74}$

The French Agency of Development started its work in Central Asia recently (January 2017 in Uzbekistan) and its primary concerns are climate change and waste management. ${ }^{75}$

Uzbekistan is also the only state with which Latvia has a bilateral agreement in the area of health and medical sciences, although similar arrangements with others are under discussion: 'Albeit with modest beginnings, Spain has caught the spirit of the EU's new stance towards Central Asia, and to a certain extent it has even acted as a leader in terms of Europe's influence in the area. ${ }^{76}$ Despite this outlook and Spain's commitment to global health during its EU presidency

73 C. Aluttis, T. Clemens and T. Krafft, 'Global Health and Domestic Policy: What Motivated the Development of the German Global Health Strategy?' Global Public Health (2015).

74 S. Peyrouse, 'France and Central Asia', EUCAM National Policy Series, vol. 9 (2012).

75 See UzDaily, 'AFD to Finance its First Project in Uzbekistan' (26 December 2016), available at https://www.uzdaily.com/articles-id-37955.htm.

76 A. González, 'Spain: A New European Motor in Relations with Central Asia?' in E. Barbé (ed.), Spain in Europe 2004-2008 (2008). 
in $2010,{ }^{77}$ health diplomacy spending has been cut back as a result of Spain's recent economic problems. ${ }^{78}$

Finland is focused on the gender equity element in its health cooperation with Central Asia - that is, on improving women's access to health care. Another example of health cooperation was the Lung Health Project in Kyrgyzstan, aimed at improving the diagnosis of lung diseases. According to Frederick Starr, Svante Cornell, and Marja Snyder, the successful implementation of the project influenced its extension to Tajikistan:

There is a good level of awareness within the region of Finnish excellence in the [field] of [...] healthcare. [...] Kyrgyz and Tajik officials all suggested that Finland should embrace these strengths and assume a greater role in promoting these areas as part of its overall program of development cooperation. ${ }^{79}$

Lithuania, the Czech Republic, Germany and Slovakia offer academic and practical training programmes for medical institutions on various medical issues: obstetrics; gynaecology; foetal cardiotocography; eye surgery; and diagnosis of cancer, etc. Similarly, individual European universities have strategic partnerships in Central Asia, such as those between medical schools in Lund (Sweden) and Karaganda (Kazakhstan) ${ }^{80}$ and similar arrangements between Italian and Kazakh universities.

For most European governments, the diplomatic emphasis with Central Asia is on trade, culture, society and the rule of law. Their strategic goals are generally confined to energy and security. While 21 of the current $28 \mathrm{EU}$ member states have embassies in Astana (Kazakhstan), senior diplomatic representation in the region is often 'non-residential'. Ireland, for example, has no embassies at all in Central Asia and its marginal approach to the region represents a boundary case:

Ireland has, in contrast with its relations with the rest of Asia, viewed Central Asia primarily through a Eurocentric lens. [...] This approach has

77 Labonté and Gagnon, 'Framing Health and Foreign Policy'.

78 K.E. Bliss (ed.), The Changing Landscape of Global Health Diplomacy (Washington, DC: csis Global Health Policy Center, 2013).

79 S.F. Starr, S. Cornell and M.O. Snyder, Finland's Development Cooperation in Central Asia and South Caucasus (Helsinki: Ministry for Foreign Affairs of Finland, 2009), p. 46.

8o Karaganda State Medical University, 'The First Experience in Strategic Partnership' (23 August 2016), retrieved from http://www.kgmu.kz/en/news/view/1740. 
had tangible implications: it has meant that Central Asia has been ignored; [...] it has reduced the potential scope of Irish aid engagement with the poorer countries of the region. ${ }^{81}$

Ireland provides indirect funding through its contributions to international agencies and deals with Central Asia in the context of EU policy. Similarly, Austrian interest in Central Asia, especially in the context of health diplomacy, is slight and, as Austria's Washington embassy suggests, 'Austria's membership in the EU [...] played a pivotal role in deepening our relations with many nonEuropean states'. ${ }^{82}$ Other EU member states, particularly those with significant diaspora populations in Central Asia, maintain varying degrees of cultural and economic contact. ${ }^{83}$

Kazakhstan and Kyrgyzstan are the states with which EU member states are most likely to have bilateral partnership arrangements that come within the framework of health diplomacy. In this case, European use of 'soft power' has been paralleled by Russian efforts. As David Lewis asserts, '[t]here is little doubt that Russia continues to be a favoured external partner for much of the [Kyrgyzstan] population'. ${ }^{84}$ In Kazakhstan, the widespread regard for European countries is much stronger and the government's 'multi-vector' foreign policy makes it receptive to health diplomacy initiatives.

Although bilateral relations are not well developed for most European countries, several support programmes implemented by international bodies, such as the WHO, UNDP and United Nations Children's Fund (UNICEF), are active in promoting better health. This support for global health measures does not, however, come within the understanding of diplomacy aimed at Central Asia, as it is not specifically responsive to the expressed needs of the recipient state. As a result, EU member states may not get the potential return that would come with initiatives honed to reflect the preferences, values and social norms of local communities. On the other hand, actions in the areas of training and accreditation reap encouraging returns. As was mentioned above, while health

81 R. Kevlihan, 'Those New States to the East of the Caspian Sea: Ireland and Central Asia', Irish Studies in International Affairs, vol. 18 (2007), p. 109.

82 Austrian Embassy Washington, 'Overview' (undated), retrieved from http://www.austria .org/overview1/.

83 N. Collins and K. Bekenova, 'European Cultural Diplomacy: Diaspora Relations with Kazakhstan', International Journal of Cultural Policy, vol. 23, no. 6, pp. 732-750.

84 D. Lewis, 'Reasserting Hegemony in Central Asia: Russian Policy in Post-2010 Kyrgyzstan', Comillas Journal of International Relations, vol. 3 (2015), p. 69. 
diplomacy embraces the efforts of both governmental and non-governmental actors, it must be informed by political priorities.

\section{Conclusions}

As Alexander Cooley and others suggest, local elites in the Central Asian states are as aware of external threats to their hegemony as they are to internal disquiet. ${ }^{85}$ They each exhibit interests in regime survival and patterns of patronage. Thus, human rights monitoring, for example, is not necessarily regarded as unproblematic, especially after the 'colour revolution' of 2003-2005. Regional elites are conscious of the need to protect themselves against or resist a perceived interventionist agenda of democracy promotion by Western states, international organizations and donor agencies. ${ }^{86}$ Clearly, health diplomacy must be cognizant of wider geopolitical issues and it would be helpful to see further research on this broader perspective, possibly to include the soft-power tactics of China, Russia and the United States.

Non-governmental and international organizations may easily be seen as overstepping their roles if they encourage criticism of the established regime. The dominant narrative is one of transition to democracy, improved human rights and market economies. Similarly, health diplomacy needs to be tutored by 'local rules' to succeed, but it does offer a more nuanced instrument for the exercise of 'soft power'.

If the focus of cooperation at the beginning of the EU's engagement with Central Asia was primarily on promoting democracy, the rule of law and human rights, from 2007 it became clear that the EU had broadened the list of 'soft issues', now including health. So far, however, the Eu has not become a well-established health actor in Central Asia, but intensified health engagement is 'better received' and 'more visible' than projects on democratization that are seen 'as long-term and often ineffective'. ${ }^{87}$ Health initiatives thus allow the $\mathrm{EU}$ to gain more influence in the region and enhance its positive image. Both the EU and its member states with an active interest have moved beyond

85 See A. Cooley, Great Games, Local Rules: The New Great Power Contest in Central Asia (Oxford: Oxford University Press, 2012); M. Laruelle. 'Central Asia as a Case Study for a Multipolar World', Asia Policy, vol. 16 (2013), pp. 162-164.

86 R. Allison, 'Virtual Regionalism, Regional Structures and Regime Security in Central Asia', Central Asian Survey, vol. 27, no. 2 (2008), p. 188.

87 S. Peyrouse, 'How Does Central Asia View the EU?', Working Paper no. 18 (Groningen: Centre for European Security Studies, 2014). 
short-term humanitarian aid to adopt long-term objectives in line with their expressed foreign policy goals. The most effective are those that respond to the needs of the Central Asian states without challenging the established order.

This article set out to draw lessons from Europe's experience in Central Asia for the role of soft power in diplomacy. In particular, it looks at how the area of health facilitates the ability of states to attract and persuade citizens of other countries of their shared interests and intentions. Health diplomacy is seen here as instrumental and purposeful in terms of foreign policy goals and not merely as a humanitarian response to other nations' perceived needs.

A central claim of many soft-power instruments is that they allow for direct dialogue with the public at large, rather than with the elite groups that normally people diplomatic circles. Health initiatives should therefore be particularly valued. It would be hard to better the reaction of this mother to the improvements that followed one initiative:

My feelings could be described as shock and surprise, followed by happiness and admiration, literally 'such as one was caught up to the third heaven'. Many things have changed, the staff are more friendly, polite and communicative. [...] I felt myself as a real mother - a woman who is physically able and was given the supreme power to give a new life. ${ }^{88}$

More broadly, this same EU intervention facilitated a dramatic improvement in maternal and infant mortality. Of course, not all health diplomacy is as rewarding in terms of outcomes, but the potential for donor/recipient net benefit is encouraging.

Moreover, the investment in training, treatment, research and construction ensures that $\mathrm{EU}$ member states can position themselves favourably with diverse foreign publics despite the vagaries of formal diplomatic relations. Health diplomacy in this form promotes influence, creates understanding and builds relationships among alumni, co-workers, researchers and direct beneficiaries. It also provides the basis for networks that are of more sustained use in soft-power terms than those based on social media that are currently in vogue. Indeed, if health diplomacy is motivated by foreign-policy objectives, more attention should be paid to relationship building than medical provision.

Health diplomacy needs to be attuned to local political and religious values, but it is more likely to reap political dividends than explicit interventions on governance standards and human rights. For both the EU and its member

88 Cited in A. Dyadchuk, G. Abuova and A. Abzullin, 'Women's Experience and Views on Changes in Childbirth', Entre Nous, vol. 74 (2011), p. 12. 
states, the sensitive use of soft power maintains relationships with emerging powers based on mutual interests and benefits.

One of the advantages of health diplomacy for smaller states and those with no traditional role in the region is membership of the $\mathrm{EU}$. This allows them to leverage the collective effort without committing many resources, but the returns in terms of political influence or popular recognition are slight. As for all member states, bilateral contacts with other countries are an unarguable priority and will never be replaced by joint European representation. Nevertheless, smaller countries may see the EU's health diplomacy as a bonus.

Health diplomacy covers a wide range of activities but offers long-term results if it is characterized by partnership, cultural sensitivity and local recognition. Health diplomacy is not philanthropy, so it must be justified by its diplomatic value to the donor and its congruence with broader foreign policy goals.

Neil Collins is Professor of Political Science at the School of Humanities and Social Sciences of Nazarbayev University in Kazakhstan He is the founding Dean of Nazarbayev University's Graduate School of Public Policy, and has held academic posts at the Universities of Liverpool, Birmingham and Ulster. Before moving to Kazakhstan, he was a Professor and Head of the Department of Government at University College Cork in Ireland. He has a Ph.D. in Political Sciences from Trinity College Dublin. His research interests include political marketing, regulation and governance, corruption, the politics of China and the $E U$.

Kristina Bekenova is a Research Assistant at the School of Humanities and Social Sciences of Nazarbayev University in Kazakhstan, where she has worked on the EL-CSID project since April 2016. Before joining the project, she was a teaching assistant in Nazarbayev University's Graduate School of Public Policy. She holds a Master's degree in International Relations from Zhejiang University, Hangzhou, China. Her research interests include cultural studies, discourse analysis, the politics of China and the $E U$.

Ainur Kagarmanova graduated with a BSc in Biology with a minor in Political Science from Nazarbayev University. Her interest in social development and multicultural cooperation has resulted in participation in several international events, including as a Central Asian youth representative at the World Humanitarian Summit Regional Consultation in South and Central Asia in 2015, and a Kazakhstani youth representative at the World Youth Summit for Peace in 2016. 